\title{
Regional differences in usage of antenatal care and safe delivery services in Indonesia: findings from a nationally representative survey
}

\author{
Vrijesh Tripathi, ${ }^{1}$ Rajvir Singh ${ }^{2}$
}

To cite: Tripathi V, Singh R. Regional differences in usage of antenatal care and safe delivery services in Indonesia: findings from a nationally representative survey. BMJ Open 2017;7: e013408. doi:10.1136/ bmjopen-2016-013408

- Prepublication history for this paper is available online. To view these files please visit the journal online (http://dx.doi.org/10.1136/ bmjopen-2016-013408).

Received 11 July 2016 Revised 26 November 2016 Accepted 8 December 2016

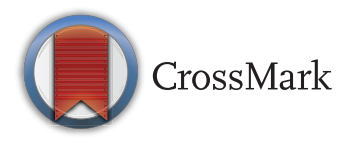

\footnotetext{
${ }^{1}$ Faculty of Science and Technology, Department of Mathematics and Statistics, The University of the West Indies, St Augustine, Trinidad and Tobago

${ }^{2}$ Cardiology Research Centre, Heart Hospital, Hamad Medical Corporation (HMC), Doha, Qatar
}

Correspondence to Dr Vrijesh Tripathi; vrijesh.tripathi@sta.uwi.edu

\section{ABSTRACT}

Background: Indonesia has shown a nominal increase in antenatal care (ANC) coverage from $93 \%$ to $96 \%$ in the Indonesia Demographic Health Survey (IDHS) 2012. This is high but for a comprehensive assessment of maternal health coverage in Indonesia, safe delivery services need to be assessed in conjunction with ANC coverage.

Materials and methods: The study uses survey data from the IDHS-2012 that was conducted among women aged $15-49$ years who gave birth during the past 3 years preceding the survey. Socioeconomic and demographic factors affecting ANC coverage and safe delivery services are analysed by segregating the data into 7 regions of Indonesia.

Results: Multivariate results show that besides wealth and education differentials, regional differences significantly affect the usage of ANC and safe delivery services across the 7 regions. Univariate analyses show that Sulawesi, Maluku and Western New Guinea islands are at a disadvantage in accessing ANC and safe delivery services.

Conclusions: The study recommends that disaggregated regional targets be set in order to further reduce maternal mortality rates in Indonesia.

\section{INTRODUCTION}

Indonesia is the second most populous country in Asia and the fourth largest in the world after the People's Republic of China, India and the USA. It consists of more than 17000 islands spread over 1.9 million square kilometres and is home to some 240 million people. There are five major islands: Sumatra, Java, Kalimantan, Sulawesi and Papua. Two remaining groups of islands are Maluku and Nusa Tenggara, running from Sulawesi to Papua in the north and from Bali to Timor in the south. The country is divided into 34 provinces that comprise some 500 districts, divided into nearly 7000 subdistricts in which there are almost 80000

\section{Strengths and limitations of this study}

- No prior study has analysed determinants of antenatal care and safe delivery services in Indonesia in a single study.

- The sampling design is robust and is representative of the country.

- The IDHS-2012 covered ever-married and nevermarried women aged 15-49 years.

- There is a recall bias because of the crosssectional design of the survey data that are selfreported at a single point of time.

- Most of the variables (age, wealth index, education, occupation) are recorded at the time of the survey rather than at the time of birth of the child and thus may have changed.

villages. ${ }^{1}$ For the purposes of this study, we have divided the country into seven regions, Sumatra, Java, Lesser Sunda islands comprising Bali, West and East Nusa Tenggara, Kalimantan, Sulawesi, Maluku islands and Western New Guinea islands.

The United Nations defined millennium development goals (MDGs) 4 and 5 were aimed at reducing under five-child mortality (U5M) by two-thirds and to improve maternal mortality ratios by three-quarters between 1990 and $2015 .^{2}$ Indonesia has recorded a huge reduction in U5M down from 85 to 27 deaths per 1000 live births in 2015. ${ }^{3}$ The international community has now defined sustainable development goals that look forward to achieving a target of reducing U5M to as low as 25/1000 live births. According to the IDHS 2012 report, while the number of mothers receiving antenatal care (ANC) has increased from $93 \%$ in 2007 to $96 \%$ in 2012 , more than half of all deliveries still take place at home in the absence of specialised services to deal with potential complications. ${ }^{5}$ The ministry of health reported a wide discrepancy in ANC usage 
across provinces with $96 \%$ mothers using ANC services in Jakarta compared with only $38 \%$ mothers in Papua province. ${ }^{6} 7$ Thus, this study assesses whether regional differences affect ANC coverage and safe delivery services across Indonesia.

\section{METHODS}

The study uses raw data from nationally representative samples of women aged 15-49 years in Indonesia Demographic and Health Survey (IDHS-2012) conducted during 7 May-31 July 2012. Among 45607 women interviewed in the survey with a $96 \%$ response rate, a total of 23809 women gave birth in the 3 years preceding the survey. There were 1558 (6.5\%) reported deaths. ${ }^{1}$

\section{Ethics statement}

The IDHS-2012 was conducted in accordance with internationally agreed ethical principles for the conduct of medical research. Since this study is based on the IDHS data, which are available in the public domain with no identifiable information on the survey participants, this work is exempted from ethical review. ${ }^{1}$

\section{Outcome events}

For the purposes of analysing ANC coverage, the study population consists of mothers who had at least three ANC visits or at least two tetanus toxoid injections during pregnancy or one tetanus toxoid injection in pregnancy and at least one tetanus toxoid injection in the preceding 3 years and received iron and folic acid tablets for 90 or more days. ${ }^{8-10}$ Safe delivery is described as delivery attended by a general practitioner or obstetrician or nurse or trained midwife who has been educated and trained to manage normal pregnancies while those attended by faith healers or elders or relatives or traditional birth attendants or others are not included in safe delivery. ${ }^{11}$

\section{Covariates}

Data were segregated according to the seven regions in Indonesia. There is merit in segregating data for it allows us to focus on aspects of ANC and safe delivery services that may remain hidden in national level indicators. ${ }^{12} 13$ Selected socioeconomic and demographic factors examined include age, place of residence, education of self and father, occupation of self and father, wealth quintile, frequency of listening to the radio/ reading newspapers and magazines, birth order and child status at birth. Though age is a continuous variable, it is tabulated into age groups $15-19$ years, 2024 years, 25-29 years and above 30 years. Place of residence is categorised as rural or urban. Education is classified as no formal education, up to primary level, up to secondary level and higher. Occupation is arranged into categories as not working outside home for money, unskilled or skilled work, or agriculture. A composite wealth index was computed using principal component analysis of household items related to possession of durable assets, access to utilities and infrastructure, and housing characteristics to assess the economic status of the mothers. Each woman was ranked based on a household asset score and was assigned to wealth quintiles, labelled as poorest, poorer, middle, richer and richest, each comprising $20 \%$ of the population. A detailed description on the methodology adopted to construct the wealth index in the IDHS data set is given in the IDHS 2012 report. ${ }^{1}$ Public messaging is an important source of getting information for the woman, and therefore the frequency of listening to the radio/reading newspapers and magazines is included to gauge the mother's level of perception regarding family health initiatives.

\section{Statistical analyses}

Data were downloaded from the DHS site with due permission for analyses. Frequencies with percentages are calculated for predictors and outcome variables. Relationships of mothers' social and demographic variables and healthcare outcomes data are stratified according to seven regions with the dependent variables as ANC coverage and safe delivery services. $\chi^{2}$ tests are performed to see associations and univariate logistic regression analysis are performed to know about ORs and 95\% CI for all predictors. Multivariate logistic regression analyses are performed and adjusted ORs with 95\% CI and $\mathrm{p}$ values are presented in the tables. ${ }^{14-16}$ Statistical significance was set at $\mathrm{p}<0.05 .{ }^{17}$ The SPSS 21.0 statistical package is used for the analyses (IBM SPSS. Statistics for windows. Version 21.0. Armonk: IBM Corp, 2012).

\section{RESULTS}

\section{Population characteristics of the study population for ANC services}

The study population of 23809 births consisted of 6833 births in the Sumatra region, 4819 births in the Java region, 2093 births in the Lesser Sunda Islands region, 2440 births in Kalimantan, 4483 births in Sulawesi, 1573 births in the Maluku Islands and 1568 births in the Western New Guinea islands (figure 1). Table 1 presents characteristics of mothers using ANC services across the seven regions, including 2744 births in the Sumatra region, 2320 births in the Java region, 847 births in the Lesser Sunda Islands, 999 births in Kalimantan, 1525 births in Sulawesi, 467 births in Maluku Islands and 559 births in the Western New Guinea islands. The table shows the number of mothers in a particular category using ANC services with the accompanying percentage of the total number of mothers in that category. As the age of the mother increases, the usage of ANC decreases across the seven regions $(\mathrm{p}=0.001)$, especially for mothers above the age of 25 years. More births took place in rural areas than urban areas in all regions except Java where more births took place in the urban 
Figure 1 Flow chart of the process of selection of mothers' sample available for analyses of antenatal care and safe delivery services.

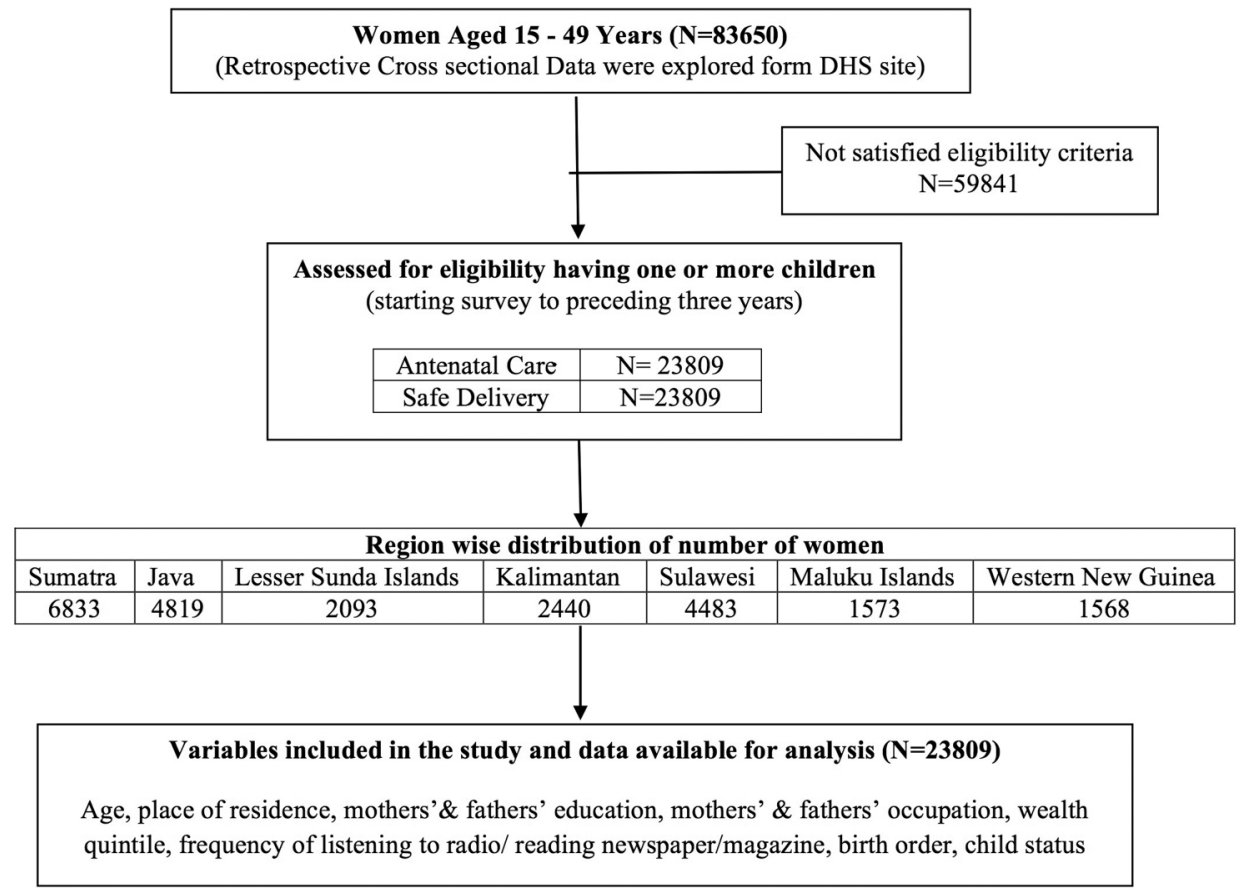

areas. Most mothers and fathers were educated up to the secondary level. The proportion of mothers using ANC services increases as the level of education of mothers and fathers increases $(p=0.001)$. Most mothers were not working outside the home across the seven regions, while most fathers were either in unskilled/ other occupations (Sumatra, Lower Sunda islands, Kalimantan, Sulawesi) or did skilled work (Java, Maluku and Western New Guinea islands). Except in Java where most mothers belonged to the richest wealth quintile, most mothers belonged to either the poorer (Sumatra, Lower Sunda islands) or poorest (Kalimantan, Sulawesi, Maluku and Western New Guinea) wealth quintiles. The frequency of listening to the radio/reading newspapers/ magazines was 'at least once a week' in all regions except Sulawesi which reported 'not at all' as the most frequent response. There were 10168 births of first order, 6483 of second order, 3468 of third order, 1731 of fourth order and 1959 of fifth and above order births. Most mothers received ANC for their first birth order and most children were born alive.

\section{Univariate analyses for ANC services}

Table 2 shows the results of univariate analyses with ORs and $95 \%$ CI of socioeconomic and demographic characteristics of mothers who received ANC services according to the seven regions. The ANC services are used by only $6-18 \%$ mothers above 30 years of age when compared with those in the 15-19 age groups across all regions. ANC services are used by $94 \%$ in the Java region (OR $0.94,95 \%$ CI 0.84 to 1.06 ), while they are used by $<50 \%$ in the Western New Guinea region (OR $0.46,95 \%$ CI 0.36 to 0.59 ) in the rural areas compared with urban areas of residence. Except for the Java island, there is a significant difference between those who use ANC services in the other six regions between the urban and rural areas. Mothers with primary and secondary level education use ANC services by two and six times, respectively, across the seven regions when compared with mothers with no formal education except in the Lesser Sunda Islands region where primary and no formal education shows no difference. Mothers with higher than secondary education also use ANC varyingly from two-and-a-half times (Lesser Sunda Islands OR 2.4, 95\% CI 1.4 to 3.9) to nine times (Western New Guinea OR 8.9, 95\% CI 5.6 to 14.4). Fathers with primary, secondary and higher than secondary level education help mothers use these services when compared with fathers with no formal education across the seven regions except in Lesser Sunda Islands where educational qualifications of fathers do not significantly affect mothers' usage of ANC services (OR $0.9,95 \%$ CI 0.5 to 1.62 ; OR $1.2,95 \%$ CI 0.7 to 2.2 and OR 1.3, 95\% CI 0.7 to 2.5), respectively. Mothers engaged in agriculture are at a significant disadvantage in using ANC services compared with those not working outside the home, skilled and unskilled workers in all the seven regions. Mothers involved in unskilled work are not at a significant disadvantage in using ANC services compared with those not working outside the home except in regions like Sumatra and Western New Guinea where the difference was significant compared with mothers not working outside the home. Father's occupation did not show any difference in the Java region, while in Kalimantan, there was a difference between skilled and unskilled workers, but there was no difference between those not working and those engaged in agriculture. In the other five regions, fathers occupied in agriculture were at a significant disadvantage in accessing ANC services compared with 
Table 1 Socioeconomic and demographic characteristics influencing the usage of antenatal care services according to regions in Indonesia, IDHS-2012

\begin{tabular}{|c|c|c|c|c|c|c|c|}
\hline Variable & $\begin{array}{l}\text { Sumatra region } \\
\text { ANC (2744) }\end{array}$ & $\begin{array}{l}\text { Java region } \\
\text { ANC (2320) }\end{array}$ & $\begin{array}{l}\text { Lesser Sunda } \\
\text { Islands region } \\
\text { ANC (847) }\end{array}$ & $\begin{array}{l}\text { Kalimantan } \\
\text { region } \\
\text { ANC (999) }\end{array}$ & $\begin{array}{l}\text { Sulawesi } \\
\text { region } \\
\text { ANC (1525) }\end{array}$ & $\begin{array}{l}\text { Maluku islands } \\
\text { region } \\
\text { ANC (467) }\end{array}$ & $\begin{array}{l}\text { Western New } \\
\text { Guinea region } \\
\text { ANC (559) }\end{array}$ \\
\hline \multicolumn{8}{|l|}{ Age (years) } \\
\hline $15-19$ & $89(75.4)$ & $92(90.2)$ & 35 (85.4) & 77 (82.8) & $108(76.6)$ & $20(66.7)$ & 19 (51.4) \\
\hline $20-24$ & $550(71.8)$ & $496(85.2)$ & $187(70.6)$ & 252 (72.6) & $362(59.9)$ & $111(54.4)$ & $90(36.3)$ \\
\hline $25-29$ & 859 (49.5) & 659 (58.1) & $254(49.7)$ & $271(47.6)$ & 386 (43.7) & $113(36.8)$ & $121(32.2)$ \\
\hline $30+$ & $1246(29.6)$ & $1043(34.8)$ & $371(29.1)$ & 399 (27.9) & 669 (23.4) & $223(21.6)$ & $143(15.8)$ \\
\hline $\mathrm{p}$ Value & 0.001 & 0.001 & 0.001 & 0.001 & 0.001 & 0.001 & 0.001 \\
\hline \multicolumn{8}{|l|}{ Place of residence } \\
\hline Urban & $1189(44)$ & $1529(48)$ & $354(48.6)$ & $434(44.3)$ & 605 (39.3) & 179 (33.9) & $163(34.2)$ \\
\hline Rural & 1555 (37.7) & 791 (46.5) & $493(36.1)$ & 565 (38.7) & $920(31.3)$ & $288(27.6)$ & $210(19.2)$ \\
\hline $\mathrm{p}$ Value & 0.001 & 0.32 & 0.001 & 0.005 & 0.001 & 0.009 & 0.001 \\
\hline \multicolumn{8}{|l|}{ Mother's education } \\
\hline No education & $27(16.4)$ & $13(21)$ & 30 (32.6) & $13(13.1)$ & 29 (12.3) & $5(12.5)$ & $41(10.3)$ \\
\hline Primary & 691 (31.3) & 615 (36.3) & 271 (32) & $322(34.1)$ & $466(25.6)$ & 115 (22.4) & $85(18.1)$ \\
\hline Secondary & $1612(43.9)$ & $1330(54.1)$ & $433(46)$ & $544(46.2)$ & $790(40.3)$ & 269 (31.5) & $181(31.7)$ \\
\hline Higher & 414 (52.5) & 332 (55.2) & 113 (53.6) & $120(54.8)$ & $240(51.6)$ & $78(47)$ & 66 (50.8) \\
\hline $\mathrm{p}$ Value & 0.001 & 0.001 & 0.001 & 0.001 & 0.001 & 0.001 & 0.001 \\
\hline \multicolumn{8}{|l|}{ Father's education } \\
\hline No education & $16(14.2)$ & $15(27.3)$ & 19 (38.8) & $14(18.7)$ & $32(17.4)$ & $6(16.7)$ & $17(8.1)$ \\
\hline Primary & 753 (3.3) & $606(38.5)$ & 280 (35.3) & 296 (32.8) & $514(28.1)$ & 96 (21.6) & 70 (17.4) \\
\hline Secondary & 1669 (44.2) & $1327(52.1)$ & $422(43.1)$ & $550(45.7)$ & 765 (38.3) & $284(31.6)$ & $217(28.8)$ \\
\hline Higher & 303 (46.5) & $341(53.8)$ & $124(45.8)$ & 139 (53.9) & $211(45.3)$ & 78 (41.5) & 65 (36.3) \\
\hline $\mathrm{p}$ Value & 0.001 & 0.001 & 0.002 & 0.001 & 0.001 & 0.001 & 0.001 \\
\hline \multicolumn{8}{|l|}{ Mother's occupation } \\
\hline Not working outside home & $1342(43.8)$ & $1210(46.8)$ & $319(42)$ & $526(44.3)$ & $811(34.8)$ & $263(31.9)$ & $201(30.1)$ \\
\hline Skilled & $814(42.3)$ & $683(49)$ & $241(45.8)$ & $277(43.9)$ & $453(39.6)$ & $130(33.6)$ & $106(36.3)$ \\
\hline Agriculture & $317(31.0)$ & $82(38)$ & $142(33.3)$ & $119(28.6)$ & $140(22.7)$ & 45 (18.3) & $48(11.4)$ \\
\hline Unskilled/others & 268 (32.8) & $313(50.4)$ & $145(38)$ & 75 (36.9) & 115 (30.5) & $29(25)$ & $16(8.7)$ \\
\hline p Value & 0.001 & 0.008 & 0.001 & 0.001 & 0.001 & 0.001 & 0.001 \\
\hline \multicolumn{8}{|l|}{ Father's occupation } \\
\hline Not working & $34(42)$ & $29(42)$ & $17(54.8)$ & $7(28)$ & $29(38.2)$ & $21(38.9)$ & $22(24.7)$ \\
\hline Skilled work & $844(45.8)$ & $1042(49.4)$ & $266(45.1)$ & $354(46.6)$ & $491(40.1)$ & $155(35.4)$ & $147(31.5)$ \\
\hline Agriculture & 764 (34.9) & $218(41.1)$ & $228(32.4)$ & 235 (32.2) & $443(27)$ & $138(22.2)$ & $97(14.8)$ \\
\hline Unskilled/others & 1049 (40.3) & 999 (47.4) & $336(43.8)$ & 403 (43.6) & 554 (36.3) & 152 (33.2) & 106 (29.9) \\
\hline p Value & 0.001 & 0.006 & 0.001 & 0.001 & 0.001 & 0.001 & 0.001 \\
\hline \multicolumn{8}{|l|}{ Wealth quintile } \\
\hline Poorest & $587(31.4)$ & $186(35.8)$ & 38 (33.6) & 328 (35.3) & $597(27.1)$ & $191(24.2)$ & $152(16.2)$ \\
\hline Poorer & 639 (41.3) & $352(45.7)$ & $187(42.9)$ & $268(41.7)$ & $328(38.7)$ & $103(29.9)$ & 65 (32.7) \\
\hline Middle & $604(45.5)$ & $447(47.2)$ & $131(46.0)$ & $176(45.8)$ & $253(38.2)$ & $86(38.6)$ & $68(38)$ \\
\hline
\end{tabular}




\begin{tabular}{|c|c|c|c|c|c|c|c|}
\hline Variable & $\begin{array}{l}\text { Sumatra region } \\
\text { ANC (2744) }\end{array}$ & $\begin{array}{l}\text { Java region } \\
\text { ANC (2320) }\end{array}$ & $\begin{array}{l}\text { Lesser Sunda } \\
\text { Islands region } \\
\text { ANC (847) }\end{array}$ & $\begin{array}{l}\text { Kalimantan } \\
\text { region } \\
\text { ANC (999) }\end{array}$ & $\begin{array}{l}\text { Sulawesi } \\
\text { region } \\
\text { ANC (1525) }\end{array}$ & $\begin{array}{l}\text { Maluku islands } \\
\text { region } \\
\text { ANC (467) }\end{array}$ & $\begin{array}{l}\text { Western New } \\
\text { Guinea region } \\
\text { ANC (559) }\end{array}$ \\
\hline Richer & $537(44.9)$ & $611(50.3)$ & $113(49.1)$ & $121(47.5)$ & $214(45.7)$ & $61(40.9)$ & $50(43.1)$ \\
\hline Richest & $377(43.6)$ & $694(50.8)$ & $108(48)$ & $106(46.5)$ & $133(44.5)$ & $26(38.8)$ & $28(37.8)$ \\
\hline $\mathrm{p}$ Value & 0.001 & 0.001 & 0.001 & 0.001 & 0.001 & 0.001 & 0.001 \\
\hline \multicolumn{8}{|c|}{ Frequency of listening to the radio/reading newspapers/magazines } \\
\hline Not at all & $222(30.2)$ & $140(34.7)$ & $242(34.5)$ & $76(33)$ & $165(22.3)$ & $115(23.3)$ & $124(15.2)$ \\
\hline Less than once a week & $48(28.7)$ & $58(52.3)$ & $30(40)$ & $16(47.1)$ & 42 (32.3) & $8(44.4)$ & $9(45)$ \\
\hline At least once a week & $2474(41.7)$ & $2092(48.6)$ & 575 (43.7) & 907 (41.7) & $1318(36.5)$ & $344(32.4)$ & 493 (32.7) \\
\hline p Value & 0.001 & 0.001 & 0.001 & 0.03 & 0.001 & 0.001 & 0.001 \\
\hline \multicolumn{8}{|l|}{ Birth order } \\
\hline First & $982(33.1)$ & $964(40.6)$ & $318(35.4)$ & 407 (36.9) & 507 (29.5) & $145(26)$ & $118(21.7)$ \\
\hline Second & $863(44.8)$ & 781 (56.3) & $236(41.8)$ & $293(44.2)$ & $438(37.5)$ & $108(27.7)$ & $90(23.5)$ \\
\hline Third & $495(49)$ & $337(56.7)$ & $15(47.8)$ & 159 (46.2) & $266(38.4)$ & 95 (36.3) & $70(27.9)$ \\
\hline Fourth & $233(49.3)$ & 107 (46.3) & $71(46.1)$ & 75 (44.6) & $156(39.2)$ & $47(31.3)$ & $39(24.9)$ \\
\hline Fifth and above & 171 (37.3) & 101 (43.2) & $72(44.4)$ & $65(40.1)$ & 158 (31.9) & 72 (33.8) & $56(23.9)$ \\
\hline p Value & 0.001 & 0.001 & 0.001 & 0.004 & & 0.02 & 0.46 \\
\hline \multicolumn{8}{|l|}{ Child status } \\
\hline Dead & 38 (10.2) & 50 (21.9) & 25 (16.2) & $22(14.8)$ & $36(10.1)$ & $12(9.4)$ & 206 (11.7) \\
\hline Alive & 2706 (41.9) & 2240 (48.8) & 822 (42.4) & 977 (42.6) & 1489 (36.1) & 455 (31.5) & 353 (25.3) \\
\hline$p$ Value & 0.001 & 0.001 & 0.001 & 0.001 & 0.001 & 0.001 & 0.001 \\
\hline
\end{tabular}




\begin{tabular}{|c|c|c|c|c|c|c|c|}
\hline Variable & $\begin{array}{l}\text { Sumatra region } \\
\text { OR and } 95 \% \mathrm{Cl}\end{array}$ & $\begin{array}{l}\text { Java region } \\
\text { OR and } 95 \% \mathrm{CI}\end{array}$ & $\begin{array}{l}\text { Lesser Sunda } \\
\text { Islands region } \\
\text { OR and } 95 \% \mathrm{CI}\end{array}$ & $\begin{array}{l}\text { Kalimantan } \\
\text { region } \\
\text { OR and } 95 \% \mathrm{Cl}\end{array}$ & $\begin{array}{l}\text { Sulawesi region } \\
\text { OR and } 95 \% \mathrm{CI}\end{array}$ & $\begin{array}{l}\text { Maluku islands } \\
\text { region } \\
\text { OR and } 95 \% \mathrm{CI}\end{array}$ & $\begin{array}{l}\text { Western New } \\
\text { Guinea region } \\
\text { OR and } 95 \% \mathrm{Cl}\end{array}$ \\
\hline \multicolumn{8}{|l|}{ Age (years) } \\
\hline $15-19$ & 1 & 1 & 1 & 1 & 1 & 1 & 1 \\
\hline $20-24$ & 0.83 (0.53 to 1.3$)$ & $0.63(0.32$ to 1.3$)$ & 0.41 (0.17 to 1.02$)$ & $0.55(0.31$ to 0.99$)$ & $0.46(0.30$ to 0.70$)$ & $0.60(0.27$ to 1.34$)$ & 0.54 (0.27 to 1.08$)$ \\
\hline 25-29 & $0.32(0.21$ to 0.50$)$ & 0.15 (0.08 to 0.3$)$ & 0.17 (0.07 to 0.41$)$ & 0.19 (0.11 to 0.33$)$ & 0.24 (0.16 to 0.36$)$ & $0.30(0.13-0.64)$ & 0.45 (0.23 to 0.89$)$ \\
\hline $30+$ & 0.14 (0.09 to 0.21$)$ & $0.06(0.03$ to 0.11$)$ & 0.07 (0.03 to 0.17$)$ & $0.08(0.05$ to 0.14$)$ & $0.09(0.86$ to 0.14$)$ & $0.14(0.06$ to 0.30$)$ & $0.18(0.09$ to 0.35$)$ \\
\hline \multicolumn{8}{|l|}{ Place of residence } \\
\hline Urban & 1 & 1 & 1 & 1 & 1 & 1 & 1 \\
\hline Rural & 0.77 (0.7 to 0.8$)$ & $0.94(0.84$ to 1.06$)$ & $0.60(0.5$ to 0.7$)$ & 0.8 (0.67 to 0.93$)$ & 0.7 (0.62 to 0.8$)$ & 0.74 (0.6 to 0.93$)$ & 0.46 (0.36 to 0.59$)$ \\
\hline \multicolumn{8}{|l|}{ Mother's education } \\
\hline No education & 1 & 1 & 1 & 1 & 1 & 1 & 1 \\
\hline Primary & $2.3(1.5$ to 3.5$)$ & 2.0 (1.2 to 3.9$)$ & 0.97 (0.6 to 1.5$)$ & 3.4 (1.9 to 6.2$)$ & 2.5 (1.6 to 3.7$)$ & $2.0(0.8$ to 5.3$)$ & 1.9 (1.3 to 2.9$)$ \\
\hline Secondary & $4.0(2.6$ to 6.1$)$ & 4.4 (2.4 to 8.2$)$ & 1.8 (1.1 to 2.8$)$ & 5.7 (3.1 to 10.3$)$ & 4.8 (3.2 to 7.2$))$ & 3.2 (1.2 to 8.3$)$ & 4.0 (2.8 to 5.8$)$ \\
\hline Higher & 5.6 (3.7 to 8.7$)$ & $4.7(2.5$ to 8.8$)$ & $2.4(1.4$ to 3.9$)$ & $8.0(4.2$ to 15.2$)$ & $7.6(5.0$ to 11.7$)$ & 6.2 (2.3 to 16.6$)$ & $8.9(5.6$ to 14.4$)$ \\
\hline \multicolumn{8}{|l|}{ Father's education } \\
\hline No education & 1 & 1 & 1 & 1 & 1 & 1 & 1 \\
\hline Primary & $3.0(1.7$ to 5.1$)$ & 1.7 (0.9 to 3.0$)$ & 0.9 (0.5 to 1.62$)$ & 2.1 (1.2 to 3.9$)$ & 1.9 (1.2 to 2.8$)$ & $1.4(0.6$ to 3.4$)$ & 2.4 (1.4 to 4.2 ) \\
\hline Secondary & $4.8(2.8$ to 8.2$)$ & $2.9(1.6$ to 5.3$)$ & $1.2(0.7$ to 2.2$)$ & $3.7(2.0$ to 6.6$)$ & $2.9(2.0$ to 4.4$)$ & $2.3(1.0$ to 5.6$)$ & 4.6 (2.7 to 7.7$)$ \\
\hline Higher & 5.3 (3.8 to 9.2$)$ & $3.1(1.7$ to 5.7$)$ & $1.3(0.7$ to 2.5$)$ & $5.1(2.7$ to 9.6$)$ & $3.9(2.6$ to 6.0$)$ & $3.5(1.4$ to 8.9$)$ & 6.4 (3.6 to 11.5$)$ \\
\hline \multicolumn{8}{|l|}{ Mother's occupation } \\
\hline $\begin{array}{l}\text { Not working outside } \\
\text { home }\end{array}$ & 1 & 1 & 1 & 1 & 1 & 1 & 1 \\
\hline Skilled & $0.9(0.8$ to 1.1$)$ & $1.1(0.9$ to 1.2$)$ & $1.2(0.9$ to 1.5$)$ & $1.0(0.8$ to 1.2$)$ & $1.2(1.1$ to 1.4$)$ & $1.1(0.8$ to 1.4$)$ & $1.3(1.0$ to 1.8$)$ \\
\hline Agriculture & $0.6(0.5$ to 0.7$)$ & $0.7(0.5$ to 0.9$)$ & $0.7(0.5$ to 0.8$)$ & $0.5(0.4$ to 0.6$)$ & $0.5(0.4$ to 0.7$)$ & $0.5(0.3$ to 0.7$)$ & $0.3(0.2$ to 0.4$)$ \\
\hline Unskilled/others & $0.6(0.53$ to 0.7$)$ & $1.2(0.9$ to 1.4$)$ & $0.8(0.7$ to 1.1$)$ & $0.7(0.5$ to 1.0$)$ & $0.8(0.6$ to 1.04$)$ & $0.7(0.45$ to 1.1$)$ & $0.2(0.1$ to 0.4$)$ \\
\hline \multicolumn{8}{|l|}{ Father's occupation } \\
\hline Not working & 1 & 1 & 1 & 1 & 1 & 1 & 1 \\
\hline Skilled work & $1.2(0.7$ to 1.8$)$ & $1.3(0.8$ to 2.2$)$ & $0.7(0.3$ to 1.4$)$ & $2.2(0.9$ to 5.4$)$ & $1.1(0.7$ to 1.7$)$ & $0.9(0.5$ to 1.5$)$ & $1.4(0.8$ to 2.4$)$ \\
\hline Agriculture & 0.7 (0.5 to 1.2$)$ & $1.0(0.6$ to 1.6$)$ & $0.4(0.2$ to 0.8$)$ & $1.2(0.5$ to 3.0$)$ & $0.6(0.4$ to 1.0$)$ & $0.4(0.3$ to 08$)$ & $0.5(0.3$ to 0.9$)$ \\
\hline Unskilled others & $0.9(0.6$ to 1.5$)$ & $1.3(0.8$ to 2.0$)$ & $0.6(0.3$ to 1.3$)$ & $1.9(0.8$ to 4.8$)$ & $0.9(0.6$ to 1.5$)$ & $0.8(0.4$ to 1.4$)$ & $1.3(0.8$ to 2.2$)$ \\
\hline \multicolumn{8}{|l|}{ Wealth quintile } \\
\hline Poorest & 1 & 1 & 1 & 1 & 1 & 1 & 1 \\
\hline Poorer & $1.5(1.3$ to 1.8$)$ & $1.5(1.2$ to 1.9$)$ & $1.5(1.2$ to 1.9$)$ & $1.3(1.1$ to 1.6$)$ & $1.7(1.4$ to 2.0$)$ & $1.5(1.0$ to 1.8$)$ & 2.5 (1.8 to 3.5$)$ \\
\hline Middle & $1.8(1.5$ to 2.0$)$ & $1.6(1.3$ to 2.0$)$ & $1.7(1.3$ to 2.2$)$ & $1.6(1.2$ to 2.0$)$ & $1.6(1.3$ to 2.0$)$ & $2.0(1.4$ to 2.7$)$ & $3.2(2.2$ to 4.5$)$ \\
\hline Richer & $1.8(1.5$ to 2.1$)$ & $1.8(1.5$ to 2.2$)$ & $1.9(1.4$ to 2.6$)$ & 1.7 ((1.3 to 2.2$)$ & $2.3(1.9$ to 2.8$)$ & $2.2(1.5$ to 3.1$)$ & 3.9 (2.6 to 5.9$)$ \\
\hline Richest & $1.7(1.4$ to 2.0$)$ & $1.9(1.5$ to 2.3$)$ & $1.8(1.4$ to 2.5$)$ & $1.6(1.2$ to 2.0$)$ & $2.2(1.7$ to 2.8$)$ & $2.0(1.2$ to 3.3$)$ & $3.0(1.9$ to 5.2$)$ \\
\hline \multicolumn{8}{|c|}{ Frequency of listening to the radio/reading newspapers/magazines } \\
\hline Not at all & 1 & 1 & 1 & 1 & 1 & 1 & 1 \\
\hline $\begin{array}{l}\text { Less than once a } \\
\text { week }\end{array}$ & $0.9(0.6$ to 1.4$)$ & $2.0(1.3$ to 3.2$)$ & $1.3(0.8$ to 2.1$)$ & 1.8 (0.9 to 3.7$)$ & $1.7(1.1$ to 2.5$)$ & $2.6(1.0$ to 6.8$)$ & 4.6 (1.9 to 11.2$)$ \\
\hline At least once a week & $1.7(1.4$ to 2.0$)$ & $1.8(1.4$ to 2.2$)$ & $1.5(1.2$ to 1.8$)$ & $1.4(1.1$ to 1.9$)$ & $2.0(1.7$ to 2.4$)$ & $1.6(1.2$ to 2.0$)$ & 2.7 (2.0 to 3.5$)$ \\
\hline
\end{tabular}

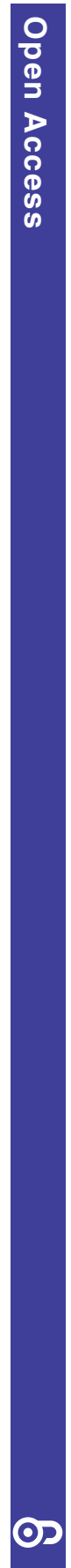




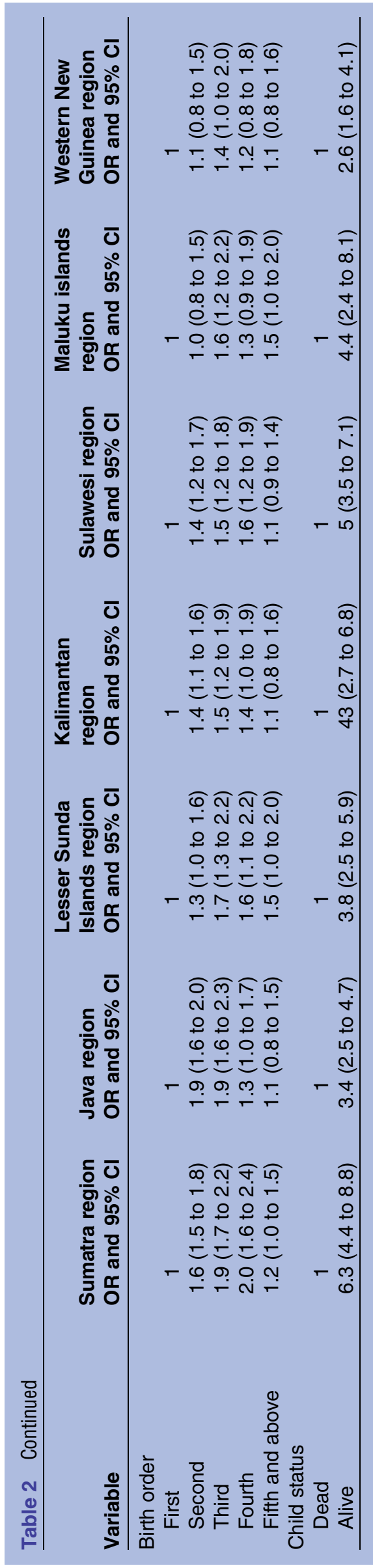

those not working, those engaged in skilled work and unskilled work. The usage of ANC services increases significantly by one-and-a-half to two times for those in poorer to richest wealth quintiles across all regions excepts Western New Guinea where it increases from two-and-a-half times to four times for those in poorer to richest quintiles compared with those in the poorest wealth quintile. The usage of ANC services in Sumatra, Lesser Sunda Islands and Kalimantan regions is not associated with listening to the radio and/or reading newspapers and magazines less than once a week compared with not listening to the radio or reading newspapers at all. Those listening to the radio and/or reading newspapers and magazines at least once a week use ANC services one-and-a-half to two times more than those who do not across all regions except in the Western New Guinea region, where ANC usage increases significantly by almost four-and-a-half times (OR 4.6, 95\% CI 1.9 to 11.2). As birth order increases from the first to third birth order, mothers show greater awareness and use ANC services compared with the first birth order across all regions. However, ANC usage shows a decreasing trend with the fourth and fifth and above birth order. Those who reported the status of child at birth as dead did not use ANC services compared with those whose child was alive at birth.

\section{Population characteristics of study population for safe delivery}

The total number of safe deliveries in Indonesia in the 3 years preceding the survey is 10071 or $42.3 \%$ of the total burden of deliveries in Indonesia. These comprised 3287 births in the Sumatra region, 2462 births in the Java region, 890 births in the Lesser Sunda Islands region, 1031 births in Kalimantan, 1558 births in Sulawesi, 406 births in the Maluku Islands and 437 births in the Western New Guinea islands. Table 3 shows the number of mothers in a particular category using safe delivery services with the accompanying percentage of the total number of mothers in that category. Most mothers who used safe delivery services were aged over 30 years. More safe deliveries occurred in rural rather than urban places of residence except in Java where it was the opposite. Most mothers and fathers were educated up to the secondary level. Most mothers were not working outside the home and most fathers were engaged in skilled work in Java, Kalimantan, Maluku and Western New Guinea islands, while they were engaged in unskilled or other work in Sumatra, Lower Sunda and Sulawesi islands. Most families were in the richest quintile in the Java islands, in the poorer wealth quintile in Sumatra islands and in the poorest wealth quintile in the rest of the five regions. Most mothers who used safe delivery services listened to the radio, read newspapers/magazines at least once a week. Most safe deliveries were of the first birth order and most children were reported to be alive. 
Table 3 Socioeconomic and demographic characteristics influencing the usage of safe delivery services according to regions in Indonesia, IDHS2012

\begin{tabular}{|c|c|c|c|c|c|c|c|}
\hline Variable & $\begin{array}{l}\text { Sumatra } \\
\text { region } \\
\text { Safe delivery } \\
(\mathbf{3 2 8 7})\end{array}$ & $\begin{array}{l}\text { Java region } \\
\text { Safe delivery } \\
(2462)\end{array}$ & $\begin{array}{l}\text { Lesser Sunda } \\
\text { Islands region } \\
\text { Safe delivery } \\
(890)\end{array}$ & $\begin{array}{l}\text { Kalimantan } \\
\text { region } \\
\text { Safe delivery } \\
(1031)\end{array}$ & $\begin{array}{l}\text { Sulawesi } \\
\text { region } \\
\text { Safe delivery } \\
(1558)\end{array}$ & $\begin{array}{l}\text { Maluku } \\
\text { islands region } \\
\text { Safe delivery } \\
(406)\end{array}$ & $\begin{array}{l}\text { Western New } \\
\text { Guinea region } \\
\text { Safe delivery } \\
\text { (437) }\end{array}$ \\
\hline \multicolumn{8}{|l|}{ Age (years) } \\
\hline $15-19$ & 90 (76.2) & $81(79.4)$ & 34 (82.9) & 70 (75.3) & $89(63.1)$ & 10 (33.3) & $18(48.6)$ \\
\hline 20-24 & 607 (79.2) & $474(81.6)$ & $190(71.7)$ & $238(68.6)$ & $347(57.5)$ & $101(49.5)$ & 99 (39.9) \\
\hline $25-29$ & $1056(60.8)$ & $740(65.2)$ & $284(55.6)$ & $288(50.6)$ & $402(45.5)$ & $111(36.2)$ & $142(37.8)$ \\
\hline $30+$ & $1534(36.4)$ & 1167 (38.9) & 382 (29.9) & 435 (30.4) & 720 (25.2) & 184 (17.8) & 178 (19.6) \\
\hline $\mathrm{p}$ Value & 0.001 & 0.001 & 0.001 & 0.001 & 0.001 & 0.001 & 0.001 \\
\hline \multicolumn{8}{|l|}{ Place of residence } \\
\hline Urban & 1502 (55.6) & $1751(55)$ & $418(57.4)$ & $509(52)$ & 707 (45.9) & $193(36.6)$ & $216(45.3)$ \\
\hline Rural & 1785 (43.2) & $711(43.5)$ & 472 (34.6) & $522(35.7)$ & 851 (28.9) & $213(20.4)$ & 221 (20.3) \\
\hline $\mathrm{p}$ Value & 0.001 & 0.001 & 0.001 & 0.001 & 0.001 & 0.001 & 0.001 \\
\hline \multicolumn{8}{|l|}{ Mother's education } \\
\hline No education & 30 (18.2) & $9(14.5)$ & $24(26.1)$ & $13(13.1)$ & $19(8.1)$ & $4(10)$ & $31(7.8)$ \\
\hline Primary & 753 (34.1) & 569 (33.5) & 239 (28.2) & $293(31)$ & $378(20.7)$ & $61(11.9)$ & $92(19.6)$ \\
\hline Secondary & $1972(53.8)$ & $1469(59.7)$ & $475(50.4)$ & $578(49.1)$ & $857(43.7)$ & $256(30)$ & $228(39.9)$ \\
\hline Higher & 532 (67.4) & 415 (69.1) & $152(72)$ & 147 (67.1) & 304 (65.4) & $85(51.2)$ & $86(66.2)$ \\
\hline $\mathrm{p}$ Value & 0.001 & 0.001 & 0.001 & 0.001 & 0.001 & 0.001 & 0.001 \\
\hline \multicolumn{8}{|l|}{ Father's education } \\
\hline No education & 33 (29.2) & $16(29.1)$ & $13(26.5)$ & $13(17.3)$ & $26(14.1)$ & $3(8.3)$ & $9(4.3)$ \\
\hline Primary & $817(35.87)$ & $556(35.3)$ & $253(31.9)$ & 265 (29.3) & $454(24.8)$ & $48(10.8)$ & $66(16.4)$ \\
\hline Secondary & 2027 (53.7) & $1470(57.7)$ & $463(47.3)$ & $592(49.2)$ & $814(40.7)$ & $264(29.4)$ & $272(36.1)$ \\
\hline Higher & 408 (62.7) & 418 (65.9) & $160(59)$ & $161(62.4)$ & $260(55.8)$ & $88(46.8)$ & $84(46.9)$ \\
\hline p Value & 0.001 & 0.001 & 0.001 & 0.001 & 0.001 & 0.001 & 0.001 \\
\hline \multicolumn{8}{|l|}{ Mother's occupation } \\
\hline Not working outside home & $1622(53)$ & $1271(49.2)$ & $353(46.5)$ & $543(45.7)$ & $849(36.5)$ & $227(27.5)$ & $241(36.1)$ \\
\hline Skilled & $998(51.8)$ & $800(57.4)$ & $283(53.8)$ & $315(49.7)$ & $508(44.4)$ & $138(35.7)$ & $138(47.3)$ \\
\hline Agriculture & $343(33.5)$ & $66(30.6)$ & $111(26.1)$ & $107(25.7)$ & $81(13.1)$ & $26(10.6)$ & $37(8.8)$ \\
\hline Unskilled/others & 321 (39.2) & 322 (51.9) & $143(37.4)$ & 64 (25.7) & 112 (29.7) & 15 (12.6) & $18(9.8)$ \\
\hline $\mathrm{p}$ Value & 0.001 & 0.001 & 0.001 & 0.001 & 0.001 & 0.001 & 0.001 \\
\hline \multicolumn{8}{|l|}{ Father's occupation } \\
\hline Not working & $41(50.6)$ & $31(44.9)$ & $17(54.8)$ & $10(40)$ & $31(40.8)$ & $23(42.6)$ & $21(23.6)$ \\
\hline Skilled work & $1148(58.8)$ & $1199(56.8)$ & $321(54.4)$ & $411(54.2)$ & $572(46.7)$ & $165(37.7)$ & $199(42.6)$ \\
\hline Agriculture & 859 (39.2) & 211 (39.8) & $200(28.4)$ & $200(27.4)$ & $352(21.4)$ & $84(13.5)$ & $67(10.2)$ \\
\hline Unskilled/others & $1236(47.4)$ & $1018(48.3)$ & 352 (45.8) & $410(44.4)$ & 593 (38.9) & 134 (29.3) & 147 (41.5) \\
\hline $\mathrm{p}$ Value & 0.001 & 0.001 & 0.001 & 0.001 & 0.001 & 0.001 & 0.001 \\
\hline
\end{tabular}

Continued 


\begin{tabular}{|c|c|c|c|c|c|c|c|}
\hline Variable & $\begin{array}{l}\text { Sumatra } \\
\text { region } \\
\text { Safe delivery } \\
(3287)\end{array}$ & $\begin{array}{l}\text { Java region } \\
\text { Safe delivery } \\
(2462)\end{array}$ & $\begin{array}{l}\text { Lesser Sunda } \\
\text { Islands region } \\
\text { Safe delivery } \\
(890)\end{array}$ & $\begin{array}{l}\text { Kalimantan } \\
\text { region } \\
\text { Safe delivery } \\
(1031)\end{array}$ & $\begin{array}{l}\text { Sulawesi } \\
\text { region } \\
\text { Safe delivery } \\
(1558)\end{array}$ & $\begin{array}{l}\text { Maluku } \\
\text { islands region } \\
\text { Safe delivery } \\
(406)\end{array}$ & $\begin{array}{l}\text { Western New } \\
\text { Guinea region } \\
\text { Safe delivery } \\
\text { (437) }\end{array}$ \\
\hline \multicolumn{8}{|l|}{ Wealth quintile } \\
\hline Poorest & $662(35.4)$ & $160(30.8)$ & 265 (28.9) & 287 (30.9) & $499(22.6)$ & $112(14.2)$ & $162(16.2)$ \\
\hline Poorer & 757 (48.9) & 348 (45.2) & $196(45)$ & $270(42)$ & $339(40)$ & $91(26.4)$ & 79 (39.7) \\
\hline Middle & $724(53.4)$ & $480(50.7)$ & $155(54.4)$ & $204(53.1)$ & $301(45.5)$ & $95(42.6)$ & $89(49.7)$ \\
\hline Richer & $655(54.8)$ & $663(54.6)$ & $138(60)$ & $140(54.9)$ & $262(56)$ & 75 (50.3) & 71 (61.2) \\
\hline Richest & 489 (56.5) & 811 (59.3) & $136(60.4)$ & $130(57)$ & 157 (52.5) & $33(49.3)$ & $36(48.6)$ \\
\hline p Value & 0.001 & 0.001 & 0.001 & 0.001 & 0.001 & 0.001 & 0.001 \\
\hline \multicolumn{8}{|c|}{ Frequency of listening to the radio/reading newspapers/magazines } \\
\hline Not at all & $259(35.2)$ & $137(33.9)$ & $208(29.7)$ & $65(28.3)$ & $131(17.7)$ & $90(18.2)$ & $120(14.7)$ \\
\hline Less than once a week & $61(36.5)$ & $63(56.8)$ & $32(42.7)$ & $17(50)$ & $37(28.5)$ & $10(55.6)$ & $10(50)$ \\
\hline At least once a week & $2967(50)$ & $2262(52.6)$ & $650(49.4)$ & $949(43.6)$ & $1390(38.5)$ & $306(28.8)$ & 307 (41.9) \\
\hline Value & 0.001 & 0.001 & 0.001 & 0.001 & 0.001 & 0.001 & 0.001 \\
\hline \multicolumn{8}{|l|}{ Birth order } \\
\hline 1 st & 1295 (43.6) & 1084 (45.7) & $387(43.1)$ & $439(39.8)$ & 598 (34.6) & $159(28.5)$ & $153(28.2)$ \\
\hline 2nd & 955 (49.6) & $820(59.1)$ & 244 (43.2) & $292(44)$ & $425(36.4)$ & $99(25.4)$ & $108(28.2)$ \\
\hline 3rd & 565 (55.9) & $350(58.9)$ & $142(45.2)$ & $157(45.6)$ & $250(36.1)$ & 69 (26.3) & $74(29.5)$ \\
\hline 4th & $263(55.6)$ & $106(45.9)$ & 63 (40.9) & 77 (45.8) & 147 (36.9) & $36(24)$ & $48(30.6)$ \\
\hline 5th and above & 210 (45.9) & $102(43.6)$ & 54 (33.3) & $66(40.7)$ & $138(27.8)$ & $43(20.2)$ & $54(23.1)$ \\
\hline p Value & 0.001 & 0.001 & 0.14 & 0.18 & 0.01 & 0.20 & 0.46 \\
\hline \multicolumn{8}{|l|}{ Child status } \\
\hline Dead & 86 (23.2) & $80(35.1)$ & $32(20.8)$ & 31 (20.8) & 51 (14.3) & $12(9.4)$ & $24(14)$ \\
\hline Alive & 3201 (49.5) & $2382(51.9)$ & 858 (44.2) & 1000 (43.6) & 1507 (36.5) & 394 (27.3) & 413 (29.6) \\
\hline $\mathrm{p}$ Value & 0.001 & 0.001 & 0.001 & 0.001 & 0.001 & 0.001 & 0.001 \\
\hline
\end{tabular}




\section{Univariate analyses for safe delivery services}

Table 4 presents the results of univariate analyses of socioeconomic and demographic characteristics of safe delivery according to seven regions in Indonesia. Mothers who are 25 years and older have significantly less chances of safe delivery compared with those in the 15-19 age group in Sumatra, Java, Lesser Sunda Islands, Kalimantan and Sulawesi, while in Maluku and Western New Guinea islands, mothers over 30 are less likely to have safe delivery. Mothers living in rural places of residence have significantly less chances of safe delivery when compared with those in urban places of residence in Sumatra, Java, Lesser Sunda Islands, Kalimantan, Sulawesi, Maluku Islands and Western New Guinea islands, respectively. The chances of safe delivery for mothers with primary and secondary and above level education increase by 2-23 times in Sumatra, Java, Kalimantan, Sulawesi and Western New Guinea islands, respectively, when compared with mothers with no formal education. Fathers' education to secondary and higher levels significantly increases the chances of safe delivery compared with those fathers with no formal education. In Kalimantan, Sulawesi and Western New Guinea, even up to primary level education of fathers shows significant difference in the usage of safe delivery services compared with fathers with no formal education. Mothers engaged in agriculture are at a disadvantage in all regions compared with mothers not working outside the home. However, mothers engaged in skilled work are significantly advantaged in using safe delivery services across all regions. Mothers who are in unskilled or other jobs are at a significant disadvantage in having safe delivery except in the Java region where there is no difference between unskilled/others and those not working outside the home (OR 1.1, 95\% CI 0.9 to 1.3 ). Fathers who are in agriculture are at a statistically significant disadvantage compared with those not working in ensuring safe delivery in all regions except the Kalimantan and Java regions. Fathers engaged in skilled work are at an advantage in all regions except the Maluku Islands region (OR $0.8,95 \%$ CI 0.5 to 1.4 ), though this association is not significant. Fathers engaged in unskilled work use safe delivery services on par with those not working except in the Western New Guinea region where they are two times more likely to have safe delivery (OR 2.3, 95\% CI 1.3 to 4.0 ). As the wealth index increases, safe deliveries increase from two to eight times in all regions. Those listening to the radio and/or reading newspapers and magazines less than once a week or at least once a week are more likely to have safe deliveries by about two to four times compared with those who do not, except in the Sumatra region. In Sumatra, as birth order increases from the first to fourth birth order, mothers use safe delivery services, though there is no difference for the fifth and above birth order compared with the first birth order. In Java, there is a significant difference from the first to third, but there is no difference for the fourth and fifth and above birth order. In Lesser Sunda islands, Sulawesi and Maluku islands, there is no significant difference between the first four birth orders, but there is a significant decline (30-40\%) in ensuring safe deliveries for the fifth and above birth order. In Kalimantan and Western New Guinea islands, there is no difference between the first and higher birth orders. Those who reported the status of child at birth as dead did not avail safe delivery services across all regions compared with those who reported the status of the child as alive at birth.

\section{Multivariate analyses}

Findings of selected socioeconomic and demographic predictors related to ANC coverage and safe delivery services after adjusting mother's age at childbirth, mother's occupation, father's occupation, frequency of listening to the radio/reading newspapers/magazines, birth order and child status are presented in table 5. Mothers residing in rural areas are only slightly more likely (OR $1.02,95 \%$ CI 0.95 to 1.1 ) to receive ANC than those living in urban areas. However, mothers living in rural areas are $14 \%$ less likely (OR $0.86,95 \%$ CI 0.80 to 0.92 ) to have safe delivery compared with those in urban areas. Different regions show significant differences in the usage of ANC. ANC usage is significantly more in Java and Lesser Sunda Islands, compared with the Sumatra and Kalimantan regions. Safe delivery services show no difference in Java and Lesser Sunda Islands but are significantly less in Kalimantan, Sulawesi, Maluku Islands and Western New Guinea islands when compared with the Sumatra region. An increase in the wealth index ensures better usage of ANC and safe delivery services. Mother's education and father's education have comparable and significant roles in the usage of ANC services and in ensuring safe delivery. No formal education is a disadvantage in the usage of ANC and safe delivery services, while higher than secondary level education of mothers is an advantage in the usage of ANC services (OR 6.2, 95\% CI 4.87 to 7.85 ) and ensuring safe delivery (OR 10.37, 95\% CI 8.06 to 13.3). Listening to the radio/reading newspapers and magazines at least once a week has an impact on usage of ANC and safe delivery services. However, listening to the radio/reading newspapers less than once a week has an impact on safe delivery but not on ANC services where not listening to the radio/reading newspapers and magazines or listening to the radio/reading newspapers and magazines less than once a week makes no difference.

\section{DISCUSSION}

This study examines the factors that affect the usage of ANC and safe delivery services in Indonesia. Since Indonesia is geographically spread over a wide area, there are regional disparities in the usage of ANC and safe delivery services across its many islands. Our study proves that there are socioeconomic and demographic 
Table 4 Univariate analyses of socioeconomic and demographic factors influencing the usage of safe delivery services according to regions in Indonesia, IDHS-2012

\begin{tabular}{|c|c|c|c|c|c|c|c|}
\hline Variable & $\begin{array}{l}\text { Sumatra region } \\
\text { OR and } 95 \% \mathrm{Cl}\end{array}$ & $\begin{array}{l}\text { Java region } \\
\text { OR and } 95 \% \mathrm{Cl}\end{array}$ & $\begin{array}{l}\text { Lesser Sunda } \\
\text { Islands region } \\
\text { OR and } 95 \% \mathrm{CI}\end{array}$ & $\begin{array}{l}\text { Kalimantan } \\
\text { region } \\
\text { OR and } 95 \% \mathrm{Cl}\end{array}$ & $\begin{array}{l}\text { Sulawesi region } \\
\text { OR and } 95 \% \mathrm{Cl}\end{array}$ & $\begin{array}{l}\text { Maluku islands } \\
\text { region } \\
\text { OR and } 95 \% \mathrm{Cl}\end{array}$ & $\begin{array}{l}\text { Western New } \\
\text { Guinea region } \\
\text { OR and } 95 \% \mathrm{CI}\end{array}$ \\
\hline \multicolumn{8}{|l|}{ Age (years) } \\
\hline $15-19$ & 1 & 1 & 1 & 1 & 1 & 1 & 1 \\
\hline $20-24$ & $1.2(0.8$ to 1.9$)$ & $1.1(0.7$ to 1.9$)$ & $0.5(0.2$ to 1.2$)$ & 0.7 (0.4 to 1.2$)$ & $0.8(0.5$ to 1.2$)$ & $2.0(0.9$ to 4.4$)$ & 0.7 (0.4 to 1.4$)$ \\
\hline $25-29$ & 0.5 (0.3 to 0.7$)$ & 0.5 (0.3 to 0.8$)$ & 0.3 (0.1 to 0.6$)$ & $0.3(0.2$ to 0.6$)$ & 0.5 (0.3 to 0.7 ) & $1.1(0.5$ to 2.5$)$ & $0.6(0.3$ to 1.3$)$ \\
\hline $30+$ & $0.2(0.1$ to 0.3$)$ & $0.2(0.1$ to 0.3$)$ & $0.1(0.04$ to 0.2$)$ & 0.1 (0.09 to 0.2$)$ & $0.2(0.1$ to 0.3$)$ & $0.4(0.2$ to 0.9$)$ & $0.3(0.1$ to 0.5$)$ \\
\hline \multicolumn{8}{|l|}{ Place of residence } \\
\hline Urban & 1 & 1 & 1 & 1 & 1 & 1 & 1 \\
\hline Rural & 0.6 (0.5 to 0.7$)$ & 0.6 (0.56 to 0.71$)$ & $0.4(0.3$ to 0.5$)$ & 0.5 (0.4 to 0.6$)$ & 0.5 (0.4 to 0.5$)$ & 0.4 (0.3 to 0.6$)$ & 0.3 (0.2 to 0.47$)$ \\
\hline \multicolumn{8}{|l|}{ Mother's education } \\
\hline No education & 1 & 1 & 1 & 1 & 1 & 1 & 1 \\
\hline Primary & 2.3 (1.6 to 3.5$)$ & $3.0(1.5$ to 6.0$)$ & $1.1(0.7$ to 1.8$)$ & $3.0(1.6$ to 5.4$)$ & 3.0 (1.8 to 4.8$)$ & $1.2(0.4$ to 3.5$)$ & 2.9 (1.9 to 4.4$)$ \\
\hline Secondary & 5.2 (3.5 to 7.8$)$ & $8.7(4.0$ to 17.7$)$ & $2.9(1.8$ to 4.7$)$ & 6.4 (3.5 to 11.6$)$ & 8.9 (5.5 to 14.3$)$ & $3.9(1.4$ to 11.0$)$ & $7.8(5.2$ to 11.7$)$ \\
\hline Higher & 9.3 (6.1 to 14.2$)$ & $13.0(6.0$ to 27.0$)$ & 7.3 (4.0 to 12.7$)$ & 13.5 (7.0 to 25.8$)$ & 21.6 (13 to 35.8$)$ & 9.4 (3.2 to 27.7$)$ & 23.0 (13.7 to 38.7 ) \\
\hline \multicolumn{8}{|l|}{ Father's education } \\
\hline No education & 1 & 1 & 1 & 1 & 1 & 1 & 1 \\
\hline Primary & $1.4(0.9$ to 2.0$)$ & $1.3(0.7$ to 2.4$)$ & $1.3(0.7$ to 2.5$)$ & 2.0 (1.1 to 3.7$)$ & 2.0 (1.3 to 3.0$)$ & $1.3(0.4$ to 4.5$)$ & $4.4(2.0$ to 8.9$)$ \\
\hline Secondary & 2.8 (1.9 to 4.2$)$ & $3.3(1.8$ to 5.9$)$ & 2.5 (1.3 to 4.8$)$ & 4.6 (2.5 to 8.5$)$ & $4.0(2.7$ to 6.4$)$ & $4.6(1.4$ to 15$)$ & 12.5 (6.0 to 24.9$)$ \\
\hline Higher & 4.0 (2.6 to 6.3$)$ & 4.7 (2.6 to 8.6$)$ & $4.0(2.0$ to 7.9$)$ & $8.0(4.1$ to 15.1$)$ & 7.7 (4.9 to 12.0$)$ & 9.7 (3.0 to 32) & $20.0(9.0$ to 40.8$)$ \\
\hline \multicolumn{8}{|l|}{ Mother's occupation } \\
\hline Not working & 1 & 1 & 1 & 1 & 1 & 1 & 1 \\
\hline Skilled & $1.0(0.9$ to 1.1$)$ & $1.4(0.3$ to 0.6$)$ & $1.3(1.1$ to 1.7$)$ & $1.2(1.0$ to 1.4$)$ & $1.4(1.2$ to 1.6$)$ & 1.5 (1.1 to 1.9$)$ & $1.6(1.2$ to 2.0$)$ \\
\hline Agriculture & 0.95 (0.40 to 0.5$)$ & 0.5 (0.3 to 0.6$)$ & $0.4(0.3$ to 0.5$)$ & $0.4(0.3$ to 0.5$)$ & $0.3(0.2$ to 0.3$)$ & $0.3(0.2$ to 0.5$)$ & $0.2(0.1$ to 0.2$)$ \\
\hline Unskilled/others & $0.60(0.5$ to 0.7$)$ & $1.1(0.9$ to 1.3$)$ & $0.7(0.5$ to 0.9$)$ & 0.5 (0.4 to 0.8$)$ & $0.7(0.6$ to 0.9$)$ & $0.4(0.2$ to 0.7$)$ & $0.2(0.1$ to 0.3$)$ \\
\hline \multicolumn{8}{|l|}{ Father's occupation } \\
\hline Not working & 1 & 1 & 1 & 1 & 1 & 1 & 1 \\
\hline Skilled work & 1.4 (0.9 to 2.2$)$ & $1.6(1.0$ to 2.6$)$ & $1.0(0.5$ to 2.3$)$ & $1.2(1.0$ to 1.4$)$ & $1.4(1.2$ to 1.6$)$ & $0.8(0.5$ to 1.4$)$ & 2.4 (1.4 to 4.0$)$ \\
\hline Agriculture & $0.6(0.4$ to 0.9$)$ & $0.8(0.5$ to 1.3$)$ & $0.3(0.2$ to 0.7$)$ & $0.4(0.3$ to 0.5$)$ & $0.3(0.2$ to 0.3$)$ & $0.2(0.1$ to 0.4$)$ & $0.4(0.2$ to 0.6$)$ \\
\hline Unskilled others & $0.9(0.6$ to 1.4$)$ & $1.1(0.7$ to 1.9$)$ & $0.7(0.3$ to 1.4$)$ & 0.5 (0.4 to 0.8$)$ & 0.7 (0.6 to 0.9$)$ & $0.6(0.3$ to 1.0$)$ & $2.3(1.3$ to 4.0$)$ \\
\hline \multicolumn{8}{|l|}{ Wealth quintile } \\
\hline Poorest & 1 & 1 & 1 & 1 & 1 & 1 & 1 \\
\hline Poorer & $1.7(1.5$ to 2.0$)$ & 1.9 (1.5 to 2.3$)$ & 2.0 (1.6 to 2.5$)$ & $1.6(1.3$ to 2.0$)$ & 2.3 (1.9 to 2.7 ) & $2.2(1.6$ to 3.0$)$ & 3.4 (2.4 to 4.7$)$ \\
\hline Middle & 2.1 (1.8 to 2.4$)$ & $2.3(1.8$ to 2.9$)$ & 2.9 (2.2 to 3.9$)$ & 2.5 (2.0 to 3.0$)$ & 2.9 (2.4 to 3.4$)$ & 4.5 (3.0 to 6.3 ) & 5.1 (3.6 to 7.2$)$ \\
\hline Richer & 2.2 (1.9 to 2.6$)$ & 2.7 (2.2 to 3.4$)$ & 3.7 (2.7 to 5.0$)$ & 2.7 (2.0 to 3.6 ) & 4.4 (3.5 to 5.4$)$ & 6.1 (4.2 to 8.9$)$ & 8.2 (5.4 to 12.2$)$ \\
\hline Richest & $2.4(2.0$ to 2.8$)$ & $3.3(2.6$ to 4.0$)$ & 3.8 (2.8 to 5.1$)$ & $3.0(2.2$ to 4.0$)$ & 3.8 (3.0 to 4.8$)$ & 5.9 (3.5 to 10.0$)$ & 4.9 (3.0 to 7.9$)$ \\
\hline \multicolumn{8}{|c|}{ Frequency of listening to the radio/reading newspapers/magazines } \\
\hline Not at all & 1 & 1 & 1 & 1 & 1 & 1 & 1 \\
\hline Less than once a week & $1.0(0.7$ to 1.5$)$ & $2.6(1.7$ to 3.9$)$ & $1.8(1.1$ to 2.9$)$ & 2.5 (1.2 to 5.3$)$ & $1.9(1.2$ to 2.8$)$ & $5.6(2.2$ to 14.6$)$ & $5.8(2.4$ to 14.2$)$ \\
\hline At least once a week & $1.8(1.6$ to 2.2$)$ & $2.2(1.7$ to 2.7$)$ & $2.3(1.9$ to 2.8$)$ & $2.0(1.5$ to 2.6$)$ & 2.9 (2.4 to 3.6$)$ & $1.8(1.4$ to 2.4$)$ & $4.2(3.3$ to 5.3$)$ \\
\hline
\end{tabular}




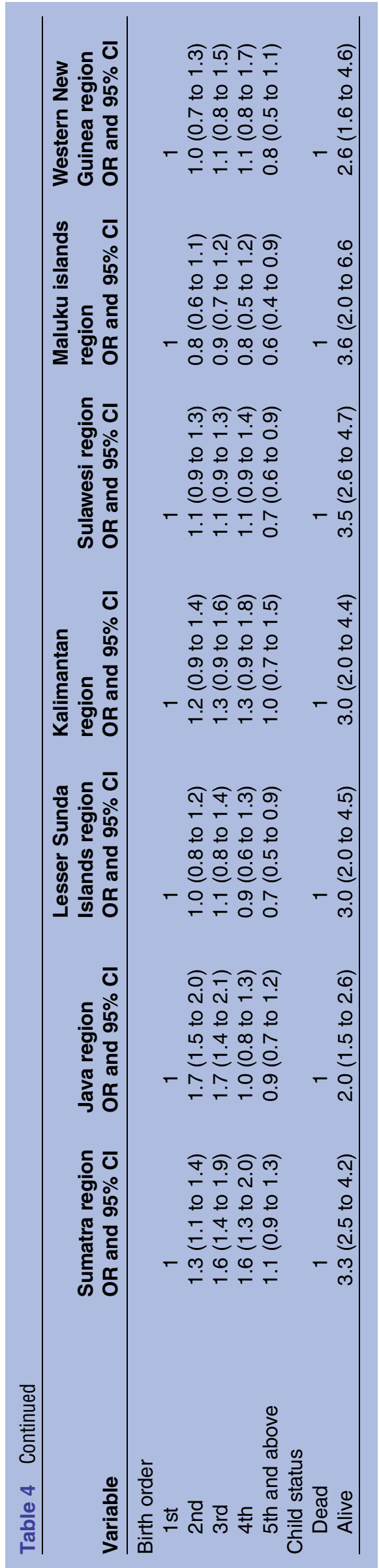

disparities that affect the use of ANC and safe delivery services and that these need to be addressed urgently.

Multivariate analyses show that there are no differences in the usage of ANC services among the rural and urban areas. This is against the disparities associated with mothers living in urban and rural areas in other studies. ${ }^{18-21}$ It is also against our own univariate findings that highlight disparities in the usage of ANC services across the seven regions. This may be due to adjusting of other important variables for ANC services like age, education and wealth quintile in the study.

Multivariate analyses reveal that compared with Sumatra, mothers in Java and Lesser Sunda islands are significantly better, mothers in Kalimantan are comparable while mothers in Sulawesi, Maluku and Western New Guinea islands are significantly disadvantaged in using ANC services. Though regional disparities are known to exist in Indonesia, multivariate results are closer to the univariate results in Java. This may be because $58 \%$ of Indonesia's population resides in Java. ${ }^{22}$ It justifies the need to disaggregate the data so that regional disparities are brought into focus.

It is known that differences in the wealth index affect mothers using ANC services. ${ }^{23-26}$ Our univariate analyses reveal that mothers in the richer and richest wealth quintiles are two times more likely in Java, Sumatra and Kalimantan and three times more likely in Sulawesi, Maluku and Western New Guinea islands to use ANC services than those in the poorest wealth quintile.

While differences in education levels of mothers and fathers affect ANC usage, mothers' education level has proved to be a significant factor in the usage of ANC services. ${ }^{7} 182027$ Mothers educated up to primary, secondary and higher levels use ANC services almost two, three and six times more than those who have received no education. It is also significant that listening to the radio/reading newspapers and magazines at least once a week significantly affects the usage of ANC services. ${ }^{7}$

Multivariate Analyses of Safe Delivery services show that safe deliveries are significantly less in rural areas compared with urban areas. ${ }^{28-30}$ While Sumatra, Java and Lesser Sunda islands are comparable in mothers' usage of safe delivery services, mothers are significantly disadvantaged in Kalimantan, Sulawesi, Maluku and Western New Guinea islands. Wealth differentials affect the use of safe delivery services, while low education levels of mothers are disadvantageous to their use of safe delivery services. Though there is no significant difference between fathers with no formal education and those educated up to only the primary level, fathers with secondary and higher levels of education are positively associated with the use of safe delivery services in Indonesia. Listening to the radio/reading newspapers and magazines also affects the use of safe delivery services positively.

Thus, in low-middle-income countries, including Indonesia, access to safe delivery services remains a great challenge. $^{31} 32$ This, along with the fact of low 
Table 5 Multivariate analyses of selected socioeconomic predictors for complete antenatal care coverage and safe delivery services in Indonesia

\begin{tabular}{|c|c|c|c|c|c|c|}
\hline \multirow[b]{2}{*}{ Variable } & \multicolumn{3}{|c|}{ Antenatal care } & \multicolumn{3}{|c|}{ Safe delivery } \\
\hline & OR & $95 \% \mathrm{Cl}$ & p Value & OR & $95 \% \mathrm{Cl}$ & p Value \\
\hline \multicolumn{7}{|l|}{ Place of residence } \\
\hline Urban & 1.0 & & & 1.0 & & \\
\hline Rural & 1.02 & 0.95 to 1.10 & 0.58 & 0.86 & 0.80 to 0.92 & 0.001 \\
\hline \multicolumn{7}{|l|}{ Region } \\
\hline Sumatra & 1 & - & - & 1 & - & - \\
\hline Java & 1.50 & 1.32 to 1.59 & 0.001 & 0.99 & 0.90 to 1.08 & 0.80 \\
\hline Lesser Sunda Islands & 1.22 & 1.08 to 1.37 & 0.001 & 0.96 & 0.86 to 1.09 & 0.54 \\
\hline Kalimantan & 1.07 & 0.96 to 1.20 & 0.23 & 0.79 & 0.71 to 0.08 & 0.001 \\
\hline Sulawesi & 0.76 & 0.70 to 0.83 & 0.001 & 0.56 & 0.51 to 0.61 & 0.001 \\
\hline Maluku Islands & 0.56 & 0.49 to 0.64 & 0.001 & 0.30 & 0.26 to 0.35 & 0.001 \\
\hline Western New Guinea & 0.46 & 0.40 to 0.54 & 0.001 & 0.44 & 0.38 to 0.51 & 0.001 \\
\hline \multicolumn{7}{|l|}{ Wealth quintile } \\
\hline Poorest & 1 & - & - & 1 & - & \\
\hline Poorer & 1.45 & 1.32 to 1.60 & 0.001 & 1.64 & 1.50 to 1.80 & 0.001 \\
\hline Middle & 1.57 & 1.42 to 1.74 & 0.001 & 1.89 & 1.70 to 2.10 & 0.001 \\
\hline Richer & 1.75 & 1.56 to 1.96 & 0.001 & 2.02 & 1.81 to 2.26 & 0.001 \\
\hline Richest & 1.52 & 1.33 to 1.73 & 0.001 & 1.72 & 1.51 to 1.96 & 0.001 \\
\hline \multicolumn{7}{|l|}{ Mother's education } \\
\hline No education & 1 & - & - & 1 & - & - \\
\hline Primary & 1.85 & 1.51 to 2.27 & 0.001 & 2.06 & 1.65 to 2.56 & 0.001 \\
\hline Secondary & 2.94 & 2.40 to 3.63 & 0.001 & 3.98 & 3.19 to 4.97 & 0.001 \\
\hline Higher & 6.20 & 4.87 to 7.85 & 0.001 & 10.37 & 8.06 to 13.3 & 0.001 \\
\hline \multicolumn{7}{|l|}{ Father's education } \\
\hline No education & 1 & - & & 1 & - & - \\
\hline Primary & 1.50 & 1.18 to 1.90 & 0.001 & 1.16 & 0.91 to 1.47 & 0.24 \\
\hline Secondary & 1.81 & 1.43 to 2.31 & 0.001 & 1.61 & 1.26 to 2.05 & 0.001 \\
\hline Higher & 1.79 & 1.37 to 2.33 & 0.001 & 1.68 & 1.28 to 2.20 & 0.001 \\
\hline \multicolumn{7}{|c|}{ Frequency of listening to radio/reading newspaper/magazine } \\
\hline Not all & 1 & & & 1 & & \\
\hline Less than once a week & 1.16 & 0.94 to 1.44 & 0.18 & 1.25 & 1.01 to 1.55 & 0.01 \\
\hline At least once a week & 1.24 & 1.13 to 1.37 & 0.001 & 1.26 & 1.15 to 1.39 & 0.001 \\
\hline
\end{tabular}

household health insurance coverage and high out-of-pocket spending on health, impedes universal health coverage. ${ }^{33}$ These need to be corrected further because regional and wealth inequalities affect maternal mortality and U5M in Indonesia.

\section{CONCLUSION}

We surmise that ANC services have increased nominally from the last IDHS survey. However, since it is still not $100 \%$, we need to look at factors affecting poor coverage by ANC and safe delivery services. Poor usage of these services is related to a complex set of social and demographic factors that affect the use, accessibility, affordability and perception about the need and utility of such services. ${ }^{34-36}$ While being poor with no formal education was a deterrent to accessing ANC services, the odds of using ANC and safe delivery services were significantly less in the Sulawesi, Maluku and Western New Guinea islands. This means that the areas covered by trained nurses/midwives are increased and special incentives are offered to train women social workers in the Sulawesi, Maluku and Western New Guinea islands. The study recommends that disaggregated regional targets be set so as to further reduce maternal mortality rates in Indonesia.

Contributors VT and RS conceived and designed the study, analysed the data, and equally contributed and reviewed drafts of the paper.

Funding This research received no specific grant from any funding agency in the public, commercial or not-for-profit sectors.

Competing interests None declared.

Provenance and peer review Not commissioned; externally peer reviewed.

Data sharing statement The DHS website provides access to data on submission and approval for a proposal of study: http://dhsprogram.com/data/ new-user-registration.cfm.

Open Access This is an Open Access article distributed in accordance with the Creative Commons Attribution Non Commercial (CC BY-NC 4.0) license, which permits others to distribute, remix, adapt, build upon this work noncommercially, and license their derivative works on different terms, provided the original work is properly cited and the use is non-commercial. See: http:// creativecommons.org/licenses/by-nc/4.0/ 


\section{REFERENCES}

1. Statistics Indonesia (Badan Pusat Statistik-BPS), National population and family planning board (BKKBN), and Kementerian Kesehatan (Kemenkes- $\mathrm{MOH}$ ), and ICF International. Indonesia demographic and health survey 2012 (IDHS 2012). Jakarta: BPS, BKKBN, Kemenkes, and ICF International, 2013.

2. United Nations. The millennium development goals report. New York: United Nations, 2015. http://www.un.org/millenniumgoals/ 2015 MDG_Report/pdf/MDG\%202015\%20rev\%20(July\%201).pdf (accessed 19 Oct 2016)

3. UNICEF. Committing to child survival: a promise renewed-progress report. New York: UNICEF, 2015. http://www.apromiserenewed.org/ wpcontent/uploads/2015/09/APR_2015_8_Sep_15.pdf (accessed 11 Nov 2016).

4. United Nations. Transforming our world: the 2030 agenda for sustainable development. New York: United Nations, 2015. http:// www.undp.org/content/dam/undp/library/corporate/brochure/SDGs Booklet_Web_En.pdf (accessed 11 Nov 2016).

5. UNICEF Indonesia. Children in Indonesia: the early years-from birth to 5 years old. Jakarta: UNICEF Indonesia, 2016. http://www. unicef.org/indonesia/children.html (accessed 9 Jun 2016).

6. Statistics Indonesia (Badan Pusat Statistik-BPS) and Macro International. Indonesia demographic and health survey 2007. Calverton, MA: BPS and Macro International, 2008.

7. Titaley CR, Dibley MJ, Roberts CL. Factors associated with underutilization of antenatal care services in Indonesia: results of Indonesia demographic and health survey 2002/2003 and 2007. BMC Public Health 2010;10:485.

8. Paul VK, Sachdev HS, Mavalankar D, et al. Reproductive health, and child health and nutrition in India: meeting the challenge. Lancet 2011;377:332-49.

9. Singh PK, Rai RK, Alagarajan M, et al. Determinants of maternity care services utilization among married adolescents in rural India. PLOS ONE 2012;7:e31666.

10. World Health Organisation. Provision of effective antenatal care: integrated management of pregnancy and childbirth (IMPAC). Standards for maternal and neonatal care (1.6), Department of making pregnancy safer. Geneva: World Health Organisation, 2006. http://www.who.int/reproductivehealth/publications/maternal_ perinatal_health/effective_antenatal_care.pdf (accessed 9 June 2016)

11. World Health Organization. Making pregnancy safer: the critical role of the skilled attendant. A joint statement by WHO, ICM and FIGO. Geneva: World Health Organization, 2004.

12. Katti V. Regional disparities in Nepal. Int Stud 1987;24:209-24.

13. Sreeramareddy CT, Harsha Kumar HN, Sathian B. Time trends and inequalities of under-five mortality in Nepal: a secondary data analysis of four demographic and health surveys between 1996 and 2011. PLOS ONE 2013;8:e79818.

14. Harrell FE. Regression modelling strategies with application to linear models, logistic regression and survival analysis. Berlin: Springer-Verlag, 2001

15. Hosmer DW Jr, Lemeshow S, Sturdivant RX. Applied logistic regression. 3rd edn. New York: John Wiley \& Sons, 2013.

16. Kleinbaum DG, Kupper LL, Muller KE, et al. Applied regression analysis and multivariable method. 3rd edn. Belmont: Duxbury Press, 1998.

17. Correia MIT, Waitzberg DL. The impact of malnutrition on morbidity, mortality, length of hospital stay and costs evaluated through a multivariate model analysis. Clin Nutr 2003;22:235-9.
18. Agus $\mathrm{Y}$, Horiuchi $\mathrm{S}$. Factors influencing the use of antenatal care in rural West Sumatra, Indonesia. BMC Pregnancy Childbirth 2012;12:9.

19. Doctor HV. Intergenerational differences in antenatal care and supervised deliveries in Nigeria. Health Place 2011;17:480-9.

20. Pallikadavath S, Foss M, Stones RW. Antenatal care: provision and inequality in rural north India. Soc Sci Med 2004;59:1147-58.

21. Ansariadi A, Manderson L, Manderson L. Antenatal care and women's birthing decisions in an Indonesian setting: does location matter. Rural Remote Health 2015;15:2959.

22. World Population Review. Indonesia population. Walnut, CA: World Population Review, 2016. http://worldpopulationreview.com/ countries/indonesia-population/ (accessed 11 Jun 2016).

23. Titaley CR, Hunter CL, Dibley MJ, et al. Why do some women still prefer traditional birth attendants and home delivery?: a qualitative study on delivery care services in West Java province, Indonesia. BMC Pregnancy Childbirth 2010;10:43.

24. Simkhada $B$, van Teijlingen ER, Porter $M$, et al. Factors affecting the utilization of antenatal care in developing countries: systematic review of the literature. J Adv Nurs 2008;61:244-60.

25. Furuta M, Salway S. Women's position within the household as a determinant of maternal health care use in Nepal. Int Fam Plan Perspect 2006;32:17-27

26. Lagarde M, Haines A, Palmer N. Conditional cash transfers for improving uptake of health interventions in low- and middle-income countries: a systematic review. JAMA 2007;298:1900-10.

27. Taguchi N, Kawabata M, Maekawa M, et al. Influence of socio-economic background and antenatal care programmes on maternal mortality in Surabaya, Indonesia. Trop Med Int Health 2003;8:847-52.

28. Ronsmans C, Scott S, Qomariyah SN, et al. Professional assistance during birth and maternal mortality in two Indonesian districts. Bull World Health Organ 2009;87:416-23.

29. Thind A, Banerjee K. Home deliveries in Indonesia: who provides assistance? J Community Health 2004;29:285-303.

30. Titaley CR, Dibley MJ, Roberts CL. Factors associated with non-utilisation of postnatal care services in Indonesia. J Epidemiol Community Health 2009;63:827-31.

31. Darmstadt GL, Lee AC, Cousens $\mathrm{S}$, et al. 60 million non-facility births: who can deliver in community settings to reduce intrapartumrelated deaths? Int J Gynaecol Obstet 2009;107(Suppl 1):S89-112.

32. Titaley CR, Dibley MJ, Roberts CL, et al. Type of delivery attendant, place of delivery and risk of early neonatal mortality: analyses of the 1994-2007 Indonesia Demographic and Health Surveys. Health Policy Plan 2012;27:405-16.

33. Harimurti P, Pambudi E, Pigazzini A, et al. NICO studies series 8: the nuts \& bolds of Jamkesmas, Indonesia's Government-financed health coverage program for the poor and near-poor. Washington DC: World Bank, 2013. http://www.indonesia-investments.com/ upload/documenten/world-bank-jamkesmas-indonesia-investments. pdf (accessed 12 Jun 2016).

34. World Health Organisation. Health statistics and information systems. Geneva: World Health Organisation, 2012. http:/www.who.int/gho/ publications/world health statistics/2012/en/ (accessed 10 Jun 2016).

35. World Health Organisation. Levels \& trends in child mortality: estimates developed by the UN inter-agency group for child mortality estimation. Geneva: World Health Organisation, 2012. http://www. childinfo.org/files/Child Mortality Report 2012.pdf (accessed 10 Jun 2016).

36. Paxton A, Wardlaw T. Are we making progress in maternal mortality? N Engl J Med 2011;364:1990-3. 